\title{
DIFFERENCES IN PLANTAR PRESSURE BETWEEN THE DIABETIC AND HEALTHY SUBJECTS
}

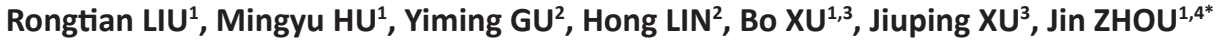

${ }^{1}$ National Engineering Laboratory for Clean Technology of Leather Manufacture, Sichuan University, Chengdu 610065, P.R.China, e-mail: zj_scu@qq.com

${ }^{2}$ Guangdong Huizhou Quality \& Measuring Supervision Testing Institute, Huizhou 516003, China

${ }^{3}$ School of Business, Sichuan University, Chengdu 610065, P.R. China

${ }^{4}$ Chengdu Anland Co., LTD, Chengdu 610065, P.R. China

Received: 19.03.2017

Accepted: 12.06.2017

https://doi.org/10.24264/Ifj.17.4.2

\section{DIFFERENCES IN PLANTAR PRESSURE BETWEEN THE DIABETIC AND HEALTHY SUBJECTS}

ABSTRACT. Since varied thresholds were reported in the literature and in what range of peak pressure is safe was not answered, the aim of this study was to compare the plantar pressure between the diabetic and healthy subjects and then to find the risk threshold of pressure for diabetic patients. 177 volunteers ( 83 diabetic patients and 94 control ones) were recruited and their plantar pressure were measured by the Emed pressure system. Plantar region was divided into seven regions: big toe, MTH1-5 and MF, under which mean pressure (kPa) was calculated. The results show that major variations existed and mean pressure of the patients was $2.5 \%$ lower than that of healthy counterparts; however, the law of differences between the diabetic patients and healthy ones in $3 \%, 50 \%$ and $96 \%$ percentile level could not be found. Overall, attention should be paid to changes in feet of diabetic patients, who must receive appropriate treatment when their mean pressure exceeds $100 \mathrm{kPa}$ (about $10 \mathrm{~N} / \mathrm{cm}^{2}$ ).

KEY WORDS: diabetic feet, foot ulcers, mean pressure, diabetic peripheral neuropathy

\section{DIFERENTE DE PRESIUNE PLANTARĂ ÎNTRE SUBIECTII DIABETICI ŞI CEI SĂNĂTOŞI}

REZUMAT. Întrucât s-au raportat praguri variate în literatură şi nu există un consens pentru intervalul de siguranţă al presiunii maxime, scopul acestui studiu a fost de a compara presiunea plantară între subiecţii diabetici şi cei sănătoşi şi apoi de a stabili pragul de risc al presiunii pentru pacienţii diabetici. Au fost recrutaţi 177 de voluntari (83 de pacienţi cu diabet zaharat şi 94 de pacienţi în grupul martor), iar presiunea lor plantară a fost măsurată utilizând sistemul de presiune Emed. Regiunea plantară a fost împărţită în şapte regiuni: degetul mare, MTH1-5 şi $\mathrm{MF}$, în care s-a calculat presiunea medie ( $\mathrm{kPa}$ ). Rezultatele arată că au existat variaţii majore, iar presiunea medie a pacienţilor diabetici a fost cu 2,5\% mai mică decât cea a subieç̧ilor sănătoşi; cu toate acestea, nu am putut stabili o lege a diferenţelor dintre subiecţii diabetici şi cei sănătoşi la niveluri de 3\%, 50\% şi 96\%. În general, trebuie să se acorde atenţie modificărilor la nivelul picioarelor pacienţilor cu diabet zaharat, iar aceştia ar trebui să beneficieze de un tratament adecvat atunci când presiunea medie depăşeşte $100 \mathrm{kPa}$ (aproximativ $10 \mathrm{~N} / \mathrm{cm}^{2}$ ).

CUVINTE CHEIE: picior diabetic, ulceraţii la nivelul piciorului, presiune medie, neuropatie periferică diabetică

\section{DIFFÉRENCES DE LA PRESSION PLANTAIRE ENTRE LES SUJETS DIABÉTIQUES ET CEUX EN BONNE SANTÉ}

RÉSUMÉ. Étant donné que des seuils variés ont été signalés dans la littérature et qu'il n’y a pas de consensus sur la gamme de pression maximale de sécurité, le but de cette étude a été de comparer la pression plantaire entre les sujets diabétiques et les sujets sains, puis de trouver le seuil de risque de pression pour les patients diabétiques. 177 bénévoles (83 patients diabétiques et 94 témoins) ont été recrutés et leur pression plantaire a été mesurée par le système de pression Emed. La région plantaire a été divisée en sept régions: le gros orteil, MTH1-5 et MF, sous lesquelles la pression moyenne $(\mathrm{kPa})$ a été calculée. Les résultats montrent qu'il y a des variations majeures et que la pression moyenne des patients a été inférieure de 2,5\% à celle des homologues sains ; cependant, nous n'avons pas pu trouver la loi des différences entre les patients diabétiques et les personnes en bonne santé dans un niveau de 3\%, 50\% et 96\%. Généralement, il faut accorder une attention particulière aux changements de pieds chez les patients diabétiques et ils doivent recevoir un traitement approprié lorsque leur pression moyenne dépasse $100 \mathrm{kPa}$ (environ $10 \mathrm{~N} / \mathrm{cm}^{2}$ ).

MOTS CLÉS: pieds diabétiques, ulcères du pied, pression moyenne, neuropathie périphérique diabétique

* Correspondence to: Jin ZHOU, National Engineering Laboratory for Clean Technology of Leather Manufacture, Sichuan University, Chengdu 610065, P.R.China, e-mail: zj_scu@scu.edu.cn 


\section{INTRODUCTION}

Diabetes Mellitus is a serious chronic disease caused by both environmental and genetic factors [1] and it was reported that by 2014 , the number of people worldwide with diabetes was over 422 million [2]. Major challenges for diabetes mellitus patients are the diabetic complications, which would induce ulceration, amputation, and even the death. Those complications absolutely could heavy the financial burden of patients, as a number of lower distal amputations and ulcers are repeatedly occurring in the diabetic feet [1]. Although deformities, trauma and peripheral neuropathy in feet are the most important factors responsible for feet ulcers, high peak pressure is the consequence of the above factors and is the direct cause of feet ulcers [1, 3-7]. Its mechanism has three steps. In the first stage, the sense of feeling is attenuated in the diabetic patient with peripheral neuropathy; meanwhile the strength of muscle and tendon is also reduced, so as to cause the feet deformities, such as the collapse of the foot arches. In the second stage, as the foot structure changed, plantar pressure would concentrate in a specific area and cause the inner tissue lesion of the feet. In the third stage, accompanied by infection, the ulcer develops in the feet [8].

Current literature reports varied ways of pressure distribution in diabetic population. Mueller [9], Delbridge [10], Murray [3] showed that excessive callus and limited joint activity increase the risk of feet ulcers. Pitei [11] and Young [12] found that the callus increased the peak pressure, while by removing callus, a $25-32 \%$ peak pressure reduction can be achieved. Boyko [13] and Ahroni [14] systematically reviewed the risk factors for diabetic feet ulcer and they concluded that feet deformities significantly increased plantar pressure and risk of diabetic ulcer; for instance, hallux valgus changed the pressure distribution in the forefoot and increased the pressure value at medial-lateral forefoot. Similarly, Ledoux [4] demonstrated that claw toes and hammer toes were strongly correlated with the high pressure and the occurrence of foot ulcers. Liu et al. [15] focused on the Chinese diabetic population and studied the correlation between the plantar pressure and occurrence of ulcers. Their outcomes implied that $69 \%$ of increased plantar pressure was found in diabetic group. However, varied thresholds in peak pressure were reported in the above literature, but variables of mean pressure which would be more helpful for indicating the foot ulcers were ignored.

Therefore, the aim of this study was to compare the mean pressure between the Chinese diabetic and healthy subject groups.

\section{METHODS}

\section{Subjects}

In total, 177 volunteers [94 healthy people (47 normal male/47 normal female) and 83 diabetic patients (male 27/female 56)] were recruited in this study. Patients without definite diabetes mellitus diagnosis, with history of ulceration or amputation, with neuropathy disease were excluded. The aim and method of this study was explained to each patient, and their agreements were received. The whole procedure was supervised by the Ethical Committee of University and the protocol followed the principles of Helsinki Declaration.

\section{Plantar Pressure Measurements}

The distribution of plantar pressure was obtained by the Emed pressure system $(0.5 \mathrm{~m}$, Novel, Germany). Emed pressure measurement system has been confirmed its reliability [16], and the system has been widely used in scientific research. A two-step initial protocol $[17,18]$ was performed by the subjects and they were guided to walk with their selected speed across the pressure plate, which was embedded in the middle of a six-meter track. Before each measurement, the system was calibrated; and then a three- to five-minute warm up period was provided. At least three successful measures in each side of the foot were required in this study.

The plantar region was divided by Automask software (Novel Automask software, Novel gmbh, Munich) into seven regions $[19,20]$ (Figure 1): big toe, the first to fifth metatarsal head (MH1-5) and Midfoot (MF), under which mean pressure $(\mathrm{kPa})$ was calculated. Since the ulcer was usually found at the mid and forefoot, those regions were more critical rather than the hind foot. Thereby the pressure distribution at hind foot was not included in this study. 


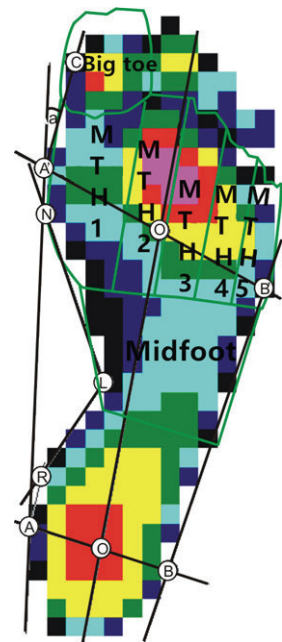

Figure 1. 7 masks for plantar area division

\section{Data Processing and Statistical Analysis}

First, inter subjects data of three measures were first averaged, and then the normal distribution was approved by the One-sample $\mathrm{K}-\mathrm{S}$ test; further, independent $\mathrm{T}$ test showed that no significant differences existed between left and right feet and they were joined together for further analysis. Both mean and percentiles value in $3 \%, 50 \%$ and $95 \%$ were calculated and contrasted by independent $\mathrm{T}$ test between diabetes and control groups. All the above analyses were based on SPSS (V16.0, SPSS Inc., Chicago) with a significant level of 0.05 and a confidence interval of $95 \%$.

\section{RESULTS}

Mean age of diabetic subjects is $63.8 \pm 9.0$ years, mean height is $160.9 \pm 7.2 \mathrm{~cm}$, mean body weight $57.9 \pm 7.6 \mathrm{Kg}$ and mean $\mathrm{BMI}$ is $22.4 \pm 2.5$; while mean age of their counterparts is $64.0 \pm 7.4$ years, mean height is $157.0 \pm 7.4 \mathrm{~cm}$, body weight is $59.5 \pm 9.6 \mathrm{Kg}$ and mean $\mathrm{BMI}$ is $24.0 \pm 3.0$.

Table 1: Comparison of the pressure of diabetic patients and healthy ones in each region $(\mathrm{kPa})$

\begin{tabular}{ccccc}
\hline Regions & Control & Diabetic & $\begin{array}{c}\text { Differences } \\
\text { (control-diabetic) }\end{array}$ & $\begin{array}{c}\text { Significant } \\
\text { value }\end{array}$ \\
\hline mean_pressure_bigtoe & $130.2 \pm 70.3$ & $123.1 \pm 42.0$ & 7.1 & 0.249 \\
mean_pressure_MH1 & $91.9 \pm 63.5$ & $119.2 \pm 47.0$ & $-27.3^{*}$ & 0.000 \\
mean_pressure_MH2 & $135.0 \pm 68.5$ & $97.9 \pm 36.8$ & $37.1^{*}$ & 0.000 \\
mean_pressure_MH3 & $132.0 \pm 56.1$ & $107.3 \pm 40.2$ & $24.6^{*}$ & 0.000 \\
mean_pressure_MH4 & $90.0 \pm 29.2$ & $90.3 \pm 33.6$ & -0.3 & 0.920 \\
mean_pressure_MH5 & $102.1 \pm 59.7$ & $105.8 \pm 46.0$ & -3.7 & 0.514 \\
mean_pressure_MF & $43.5 \pm 16.7$ & $53.0 \pm 21.0$ & $-9.5^{*}$ & 0.000 \\
mean_of_all_regions & $103.8 \pm 27.4$ & $99.6 \pm 33.0$ & $4.2^{*}$ & 0.029 \\
\hline
\end{tabular}

* significant of differences $<0.05$

As shown in Table 1, the mean pressure in the control group was $4.2 \%$ higher than that of diabetic group $(p=0.029<0.05)$; moreover, $\mathrm{MH1}, 2,3$ and MF were also recorded with significant differences between the two groups, where $\mathrm{MH} 1$ and $\mathrm{MF}$ of diabetic were significantly higher than that of their counterparts ( $p=0.000<0.05$ for all variables). $3 \%$ of the data represented lower bound of all the subjects' pressure distribution, mean pressure of diabetic patients in the toe region and MTH1 were $27.8 \%$ and $20.0 \%$ higher than those of their counterparts; while, those at 2-3 MTH were $19.9 \%$ and $21.5 \%$ lower (Figure $1 \mathrm{~A}$ ). In terms of
$50 \%$ of the data which indicated the common pressure value of all the subjects, mean pressure of diabetic patients at MTH1 and MTH5 were $50.0 \%$ and $22.6 \%$ larger than those of control subjects, with the exception that pressure at MTH2 of diabetic patients was $23.9 \%$ lower (Figure 1B). In terms of $95 \%$ of data, overall, the healthy subject showed a larger pressure distribution in major areas $(31.6 \%$ for hallux, $33.4 \%$ for MTH1, 21.8\% for MTH2, 24.2\% for MTH3 and $6.6 \%$ for MTH5 higher than those of the diabetic patients) (Figure 1C). 


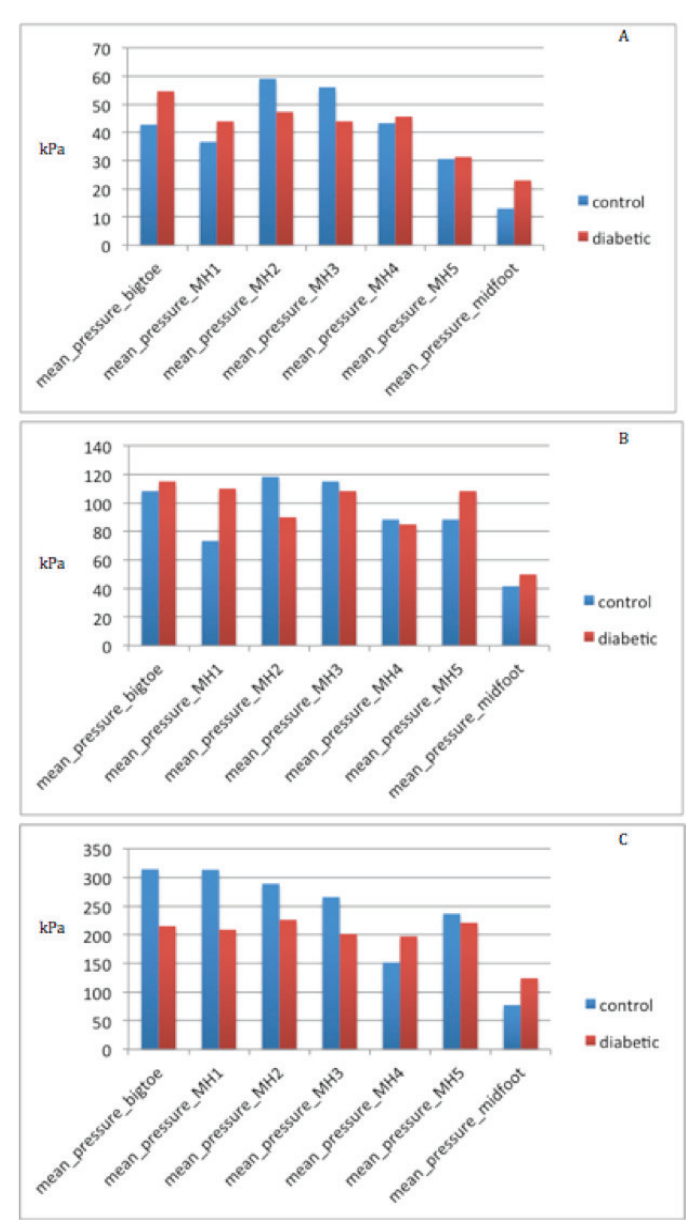

Figure 2. Comparison of $3 \%, 50 \%$ and $96 \%$ of peak pressure between the diabetic and control group (A: percentile data of 3\%; B: percentile data of $50 \%$; C: percentile data of $96 \%$ )

\section{DISCUSSION}

In this study, foot pressure data was measured from 83 diabetics and 94 control subjects, and their data were compared in $3 \%$, $50 \%$ and $95 \%$ percentile level. The results show that major variations existed and mean pressure of the patient was $4.2 \%$ lower than that of their healthy counterparts; however, the rules of differences between the diabetic patients and healthy ones in $3 \%, 50 \%$ and $96 \%$ percentile level could not be found.

The results showed that the pressure values of diabetic subjects were similar or lower than that of healthy ones and this finding was quite different from current literature. The risk range of pressure for diabetic patients was recorded by a 30 months prospective study of 86 diabetics and Veves summarized risk pressure value from patients whose high foot pressure had foot ulcers that was $\geq 10 \mathrm{~kg} / \mathrm{cm}^{2}$ (about $1000 \mathrm{kPa}$ ) which was considered as the risk threshold for occurrence of foot ulcers [6]. Meanwhile, Bus [5] found a peak pressure of diabetic feet was more than $600 \mathrm{kPa}$ in a specific MTH area. In another study concerning therapeutic footwear for diabetic patients which was prescribed to reduce the risk of ulceration [21], regions of interest with peak pressure $200 \mathrm{kPa}$ were selected as target for pressure relieving. Hence Bus concluded that $200 \mathrm{kPa}$ of peak pressure or $100 \mathrm{kPa}$ of mean pressure was in risk situation. Similarly, Boyko [13] demonstrated a higher risk of foot ulcer among patients with a peak plantar pressure of $12.3 \mathrm{~kg} / \mathrm{cm}^{2}$ (about $1230 \mathrm{kPa}$ ); further Veves [6] suggested that this value was the threshold between the normal and abnormal pressure distribution.

The authors postulated that the differences might be due to the variables selected. As 
most of the reports used the peak pressure to describe the plantar pressure distribution and it indicated the instance value when loading; while those of the mean pressure were constant and represented a relative force applying in a specific region. So the authors assumed that the mean pressure was more effective to indicate the ulcer, but there are few studies that discuss mean pressure and ulceration.

Additionally, the results also showed that the highest mean pressure of diabetic patients occurred at the MF and MTH1, which were $29.6 \%$ and $18.4 \%$ higher than that of healthy control group (Table 1); the authors suggested that tissues under these two sites became stiff and thin, which were also observed in our other study [15], where the subcutaneous tissue of diabetic patients was thinner than that of healthy counterparts. Moreover, no severe foot deformities were found in our diabetic group, thereby no significant differences between the two groups were obtained. Further, no rules of differences between the diabetic patients and healthy ones in $3 \%, 50 \%$ and $96 \%$ percentile level were found and it implied that the pressure distribution of diabetic patients varied in each other.

\section{CONCLUSION}

Overall, although no rules were found between the diabetic and healthy population in terms of mean pressure distribution and mean pressure exceeded $100 \mathrm{kPa}$ in some regions, the authors recommended that patients even with the mean pressure higher than $100 \mathrm{kPa}$ shall take care and caution; and more important, cushion footwear should be prescribed and used by them while walking.

\section{Acknowledgement}

The authors thank the financial support from China Postdoctoral Science Foundation (2015M571896) and project from Chengdu Science and Technology Administration (2015-HM01-00039-SF).

\section{REFERENCES}

1. International Diabetes Foot Working Group, Beijing: People's Military Medical Publishing House 2003.

2. WHO, http://www.presstv.ir/

Detail/2016/04/06/459437/diabetes-WHOstudy-Lancet.

3. Murray, H.J., Young, M.J., Hollis, S. et al., Diabet Med, 1996, 13, 979-982.

4. Ledoux, W.R., Shofer, J.B., Smith, D.G. et al., J Rehabil Res Dev, 2005, 42, 665-672.

5. Bus, S.A., Maas, M., de Lange, A. et al., J Biomech, 2005, 38, 1918-1925.

6. Veves, A., Murray, H.J., Young, M.J., Boulton, A.J., Diabetologia, 1992, 35, 660-663

7. Fernando, D.J., Masson, E.A., Veves, A. et al., Diabetes Care, 1991, 14, 8-11.

8. Abbott, C.A., Vileikyte, L., Williamson, S. et al., Diabetes Care, 1998, 21, 7, 1071

9. Mueller, M.J., Diamond, J.E., Delitto, A. et al., Phys Ther, 1989, 9, 453-462.

10. Delbridge, L., Perry, P., Marr, S. et al., Diabet Med, 1988, 5, 333-337.

11. Pitei, D.L., Foster, A., Edmonds, M., J Foot Ankle Surg, 1999, 38, 251-255.

12. Young, M.J., Cavanagh, P.R., Thomas, G. et al., Diabet Med, 1992, 9, 55-57.

13. Boyko, E.J., Ahroni, J.H., Stensel, V. et al., Diabetes Care, 1999, 22, 1036-1042.

14. Ahroni, J.H., Boyko, E.J., Forsberg, R.C., Diabetes Care, 1999, 22, 965-972.

15. Yaoxia, L., Bo, X., Jin, Z. et al., Chinese Journal of Diabetes, 2011, 3, 5, 371-375.

16. Maetzler, M., Bochdansky, T., Abboud, R.J., Gait Posture, 2010, 32, 391-394.

17. Bus, S.A., de Lange, A., Clin Biomech, 2005, 20, 892-899.

18. Nicholson, D.E., Armstrong, P.F., MacWilliams, B.A. et al., Gait Posture, 1998, 7, 146.

19. Ute, W., Foot Ankle Surg, 2004, 10, 121-124.

20. Kernozek, T.W., Elfessi, A., Sterriker, S., J Am Podiatr Med Assoc, 2003, 93, 97-103. 
21. Bus, S.A., Haspels, R., Buschwestbroek, T.E., Diabetes Care, 2011, 34, 7, 1595.

22. Veves, A., Sarnow, M.R., Giurini, J.M. et al., Diabet Med, 1995, 12, 585-589.
(C) 2017 by the author(s). Published by INCDTP-ICPI, Bucharest, RO. This is an open access article distributed under the terms and conditions of the Creative Commons Attribution license (http://creativecommons.org/licenses/ by/4.0/). 